\title{
Development of E-Module Android Based on Basic Competence to Apply Plantation Results in SMK PPN Lembang
}

\author{
Sopa Zahra, Sri Handayani*, Mustika Nuramalia Handayani \\ Agroindustry Technology Education Study Program \\ Universitas Pendidikan Indonesia \\ Bandung, Indonesia \\ sopazahra@student.upi.edu,*srihandayani@upi.edu
}

\begin{abstract}
Student Learning Resources XI Agribusiness processing agricultural products (APHP) SMK PPN Lembang is still very limited, causing learners do not have a handbook for independent study. There are $56 \%$ of learners get a value less than the minimum submission criteria (KKM) on material applying rubber plantation, coconut, palm oil caused by the less interesting learning processes that only uses PowerPoint media, and inserted some video. The purpose of this research is to develop learning media, know the feasibility of learning media, and know the learning outcomes of students after conducting an android-based e-module product trial. The development of this learning media uses ADDIEs development model (analyze, design, development, implementation, evaluation). The software used to produce the products of this Android-based e-module application is Microsoft PowerPoint, iSpring, Canva, website 2APK, and Java set up. The results of this study showed that this android-based e-module learning media was "very decent" by the media experts, and was declared "feasible" by material experts and linguists. Respondents stated that the learning media was "very worthy" to be developed.
\end{abstract}

\section{Keywords-e-modules, media, learning outcomes, iSpring}

\section{INTRODUCTION}

In the learning process, the media has quite an important meaning because in these activities teaching materials that are difficult to understand can be conveyed with the help of the media as an intermediary. Media can represent what the teacher is less able to say through certain words or sentences [1]. The learning process using media in the classroom will be more varied, attract the attention of students, and clarify messages so that it can improve learning outcomes.

The author has made preliminary observations at Vocational High School PPN Lembang when implementing the Education Unit Field Introduction Program (PPLSP) in September-December 2019. Based on observations, it is known that learning resources that can be accessed by students are still very limited. Students only use one textbook on the subject of Plantation and Herbal Commodity Processing
Production. On the other hand, almost all students have smartphones that can be used as learning media and can be used during the implementation of the end of semester assessments that are already online based.

From the learning results of the students obtained during the PPLSP, it is known that $56 \%$ of the students in class XI APHP 2 have not reached the minimum completeness criteria. Based on the interview with the tutor teacher, this was caused by the use of media used by educators only in the form of PowerPoint media and video shows, so that students were less interested in learning the material. Also, the method used during the learning process is the lecture method. In terms of avoiding shortages of learning outcomes and boredom during the learning process, innovative and varied learning media are needed, not only presenting theory but also needing to display images and videos.

A good learning process can occur if there is support from quality learning resources or teaching materials [2]. Current technological developments can produce various changes, especially in terms of learning media for students. To produce a learning process with good quality, interactive, interesting, it is necessary to have teaching materials based on electronic modules (e-modules). E-module is a media or means of learning an electronic version of a module that contains materials, methods, limitations of learning material, and ways of evaluating which are designed systematically and attractively to achieve the expected competencies according to the level of complexity electronically [3].

The e-module learning media has its advantages, namely that learning activities can be carried out independently because of the assistance of the learning process using a smartphone, students will not be bored in learning the material presented by the e-module and can be used without the internet. The weakness of this media is that modifying the media requires careful planning and requires a long time[4].

Based on the above background, this research will focus on developing e-module learning media on the subject of 
Plantation and Herbal Commodity Processing Production (PPKPH) in class XI APHP on basic competence 3.3 applying the processing of rubber, coconut, oil palm plantations. Therefore, the researcher conducted entitled "Development of Android-Based E-Modules on Basic Competencies of Implementing Plantation Products at Vocational High Schools of PPN Lembang".

\section{RESEARCH METHODS}

This study uses the Research and Development (R\&D) method with the ADDIE (Analyze, Design, Development, Implementation, Evaluation) development model. This study used a total sample technique with a total sample size of 50 students of class XII APHP as respondents to measure the feasibility of the e-module to be tested on students. The instruments used for data collection in this study were validation sheets for media, material, and language experts, as well as student response sheets as respondents.

\section{A. Research Procedure}

This research was conducted in five stages, namely the analysis, design, development, implementation, and evaluation stages. At the analysis stage, the researcher will analyze all the things that are used as the basis for designing and developing the product. Researchers will analyze the needs of students, learning materials, and products.

At the design stage, the researcher begins to create a media design (storyboard) which is an overview of the media as a whole that will be loaded in the application. Also, the making of flowcharts aims to assist the design of the navigation structure from one view to the next so that the media creation design can be seen clearly. The design of the instrument when data collection was carried out by making a validation sheet grid which would be filled in by the validator (media expert, material expert, and linguist) as well as a student response questionnaire.

The development stage is the product realization stage. After that, the e-module will be validated by judgment, namely material experts, media experts, and linguists. Students can use e-module learning media in the classroom creatively and interactively, this is done to determine the increase in student learning outcomes after using the developed learning media.

The following are the steps in implementing the development of e-module learning media:

1) Product trial: Product trials were carried out on class XII students totaling 50 people. Students respond to the learning media developed, then students are given a questionnaire to find out the students' responses after using emodule learning media. Also, students are directed to try to fill out 10 practice questions in essays and 20 multiple-choice questions (quiz).

2) Revision: If based on the data obtained in the making of learning media there are still deficiencies, then product improvements will be carried out which are then consulted with experts so that solutions related to product improvements that have been designed will be obtained.

The evaluation stage is the last stage of developing instructional media. At this stage, the questionnaire that has been filled in by students which contain suggestions and input will be processed. Then the learning media will be improved, to produce learning media that is under with the expected user response. This last revision is useful for conformity between the learning media developed with the needs of students.

\section{B. Data Analysis}

The data analysis technique from the validation sheet is carried out by presenting the learning media rating based on the value given by media experts, material experts, and linguists to be a feasibility score. The feasibility score is the raw score obtained and then converted into a percentage with the formula:

$\%$ interpretation score $=\frac{\text { total acquisition score }(X)}{\text { maximum score }(\mathrm{Xi})} \times 100 \%$

1) Media expert validation

TABLE I. CRITERIA FOR THE MEDIA EXPERT SCORE SCALE

\begin{tabular}{|c|c|}
\hline Percentage Criteria (\%) & Validation Level \\
\hline $81.26 \%-100 \%$ & Very worthy \\
\hline $62.51 \%-81.25 \%$ & Well worth it \\
\hline $43.76 \%-62.5 \%$ & Not feasible \\
\hline $25 \%-43.75 \%$ & Very unworthy \\
\hline
\end{tabular}

\section{2) Material expert validation}

TABLE II. CRITERIA FOR THE MATERIAL EXPERT SCORE SCALE

\begin{tabular}{|c|c|}
\hline Percentage Criteria (\%) & Validation Level \\
\hline $81.26 \%-100 \%$ & Very worthy \\
\hline $62.51 \%-81.25 \%$ & Well worth it \\
\hline $43.76 \%-62.5 \%$ & Not feasible \\
\hline $25 \%-43.75 \%$ & Very unworthy \\
\hline
\end{tabular}

\section{3) Linguist validation}

TABLE III. CRITERIA FOR THE LINGUIST SCORE SCALE

\begin{tabular}{|c|c|}
\hline Percentage Criteria (\%) & Validation Level \\
\hline $81.26 \%-100 \%$ & Very worthy \\
\hline $62.51 \%-81.25 \%$ & Well worth it \\
\hline $43.76 \%-62.5 \%$ & Not feasible \\
\hline $25 \%-43.75 \%$ & Very unworthy \\
\hline
\end{tabular}




\section{4) Validation of test items}

TABLE IV. CRITERIA FOR TEST QUESTION SCALE

\begin{tabular}{|c|c|}
\hline Percentage Criteria (\%) & Validation Level \\
\hline $81.26 \%-100 \%$ & Very worthy \\
\hline $62.51 \%-81.25 \%$ & Well worth it \\
\hline $43.76 \%-62.5 \%$ & Not feasible \\
\hline $25 \%-43.75 \%$ & Very unworthy \\
\hline
\end{tabular}

5) Student response questionnaire data analysis: The results of the participant questionnaire responses to the emodule were interpreted based on the total percentage obtained by looking at the formula for the percentage of student response data in Table 5 according to Akbar [5].

TABLE V. INTERPRETATION OF STUDENT'S RESPONSE PERCENTAGE VALUE

\begin{tabular}{|c|c|}
\hline Percentage Criteria (\%) & Validation Level \\
\hline $81.26 \%-100 \%$ & Very worthy \\
\hline $62.51 \%-81.25 \%$ & Well worth it \\
\hline $43.76 \%-62.5 \%$ & Not feasible \\
\hline $25 \%-43.75 \%$ & Very unworthy \\
\hline
\end{tabular}

\section{RESULTS AND DISCUSSION}

\section{A. Analysis}

The Production Subject of Plantation Commodity Processing and Herbs is one of the productive subjects at SMK PPN Lembang. The analysis carried out by researchers was carried out using field observations during the implementation of the Education Unit Field Introduction Program at SMK PPN Lembang. The material discussed in this research is KD 3.3. Implementing the processing of rubber, coconut, and oil palm plantations. In this material, the learning outcomes of students during the exam reached $56 \%$ of students who scored less than the KKM. This can be caused by the lack of attractive teaching materials applied to students. Also, learning resources that can be accessed by students are still very limited. The learning process carried out by the teacher usually uses the BSE textbook which is only lent to students when the subject is taking place. This causes students not to have handbooks for independent learning.

If the availability of learning resources is used in limited conditions, it can affect the quality of student learning outcomes and can lead to low learning outcomes obtained [6]. Effective learning is a learning process that uses a variety of learning resources [7].

The textbooks provided by the school can only be used when they are at school and when the subject is taking place, so students cannot study independently because they do not have handbooks when they are outside of school. Therefore, researchers hope that students can understand the material easily because of the existence of Android-based e-module learning media, students can learn anytime and anywhere [8]
SMK PPN Lembang provides several facilities that can be used by students. One of these facilities is a Wi-Fi internet connection. On the other hand, almost all students have smartphones that can be used as learning media. Students carry out end-of-semester assessments in schools that are online based, but not all students have smartphones. When the end of semester assessment takes place, students who do not have a smartphone can do the final semester assessment in the ICT room.

The development of android-based e-module learning media is expected to be used to support the learning process independently and assist the implementation of distance learning due to the pandemic so that android-based e-module learning media are needed that can help students in the learning process. In this e-module, besides providing material, videos, pictures, animations, and designs are presented that are made as attractive as possible so that the learning process is not boring.

\section{B. Design}

Design is a stage that is carried out in the process of designing an Android-based e-module learning media which will be developed in the form of an application. The process of designing an android-based e-module is as follows:

- Compile an outline of the contents of the e-module (Flowchart)

- Develop an e-module framework (storyboard)

- Arrange the content of e-module learning

\section{Development}

1) Learning media development: Development is the realization stage of the design stage. Creating an android based e-module requires several applications such as ispring, canva, website 2 APK, powerpoint and, java set up. The whole development of an android-based e-module application uses a power point application equipped with the iSpring software, then published with the 2APK website application so that in making this android-based e-module does not require coding. In the development stage, this android-based e-module will be validated by media experts, material experts and linguists who will then provide suggestions for improvements.

2) Learning media validation: At this stage, application testing is carried out by media experts, material experts, and linguists to determine the appropriateness of the application before it is implemented to students. The validation is carried out online.

3) Media validation: Media experts make an assessment of the learning media that has been developed whether it is feasible or not to be tested on students. Media is one of the factors that can support the success of the learning process of students because it can help students find information. This is done to make it easier to use the application that the module as a learning medium must be user friendly, that is, friendly with 
the wearer. The ease with which users respond and access according to their wishes and use simple, easy to understand language and use commonly used terms is a form of user friendly.

The results of the validation of learning media by media experts, the display quality aspect got a percentage of $85 \%$, the software engineering aspect got a percentage of $87.5 \%$, the implementation aspect got a $100 \%$ percentage, the interface aspect got a percentage of $83.3 \%$, and the compatibility aspect got a $100 \%$ percentage. Based on the criteria in the table, the average percentage result of all these aspects is $88.6 \%$ including in the "very good" category and declared "very feasible" to be used in the learning process. The product can be categorized as good if the assessment criteria reach 50\% [9].

4) Material validation: Material experts assess the material included in the learning media developed. The validity test of material experts consists of assessing aspects of the suitability of the material with $\mathrm{SK}$ and $\mathrm{KD}$, aspects of material accuracy, and aspects of encouraging curiosity which is then used as indicators to assess the feasibility of e-module applications. The results of material expert validation, the author is given suggestions for making improvements in learning media, namely adding a glossary, adding several other sources regarding the material raised in the making of emodules, and adding illustrations or pictures to each material described to make the material look more attractive. and make it easier for students to understand the material presented.

The validation of e-module learning material experts as a whole gets an average value of $75 \%$. Based on the assessment, the completeness of the Android-based e-module learning material is categorized as "feasible" to be used with revisions according to the suggestions given. The result data obtained has exceeded $50 \%$, so that it can make learning media suitable for use in the learning process [9].

5) Language validation: Linguists assess the material included in the learning media developed. The linguist validity test consists of assessing straightforward, communicative, dialogic, and interactive aspects, suitability with student development, conformity with language rules, and use of terms, symbols, or icons which are then used as indicators to assess the feasibility of the e-module application.

The results of the validation of learning media in the straightforward aspect get a percentage of $100 \%$, the communicative aspect gets a percentage of $75 \%$, the dialogical and interactive aspects get a percentage of $75 \%$, the conformity aspect with the development of students gets a percentage of $75 \%$, the conformance aspect with language rules gets a percentage of $75 \%$, use of the term symbol or icon gets a percentage of $75 \%$. The average percentage result obtained from all aspects was $81.25 \%$ included in the "good" category and declared "feasible" based on the criteria in Table 3.8. The result data obtained has exceeded $50 \%$, so that it can make learning media suitable for use in the learning process [9].
The use of straightforward language and clarity of sentences is important as one of the characteristics of communicative media. A module should meet the rules of being user friendly [10]. Every instruction and information exposure that appears is helpful and friendly to the wearer, including the ease with which the user responds and accesses as desired. The use of simple language, easy to understand, and using commonly used terms, is a form of user friendly.

6) Validation of test items: The validity test of the test questions consists of assessing the suitability of the material with the questions, the composition of the questions, and the language used in the questions which are then used as indicators to assess the feasibility of the e-module application. The validation of the e- module learning test questions as a whole got an average value of $81.25 \%$. Based on the assessment, the completeness of the Android-based e-module learning material is categorized as "feasible" to be used with revisions according to the suggestions given.

\section{Implementation}

The implementation stage is the experimental stage in using the learning media that has been made. This implementation involved students of class XII APHP 1 and XII APHP 2 SMK PPN Lembang who had studied the material in the application in the previous semester. Data collection is carried out online by creating a group with students on the WhatsApp application. Researchers provide an application download link and a google form questionnaire link in a group of 50 students. Students are asked to download and install an Android-based e-module learning media application. The questionnaire given to students has 4 aspects of assessment, namely the quality of the emodule application, the display of the e-module, the delivery of the material, and the benefits of the e-module in the learning process.

The results of the implementation of learning media by students when viewed from the quality aspect of the e-module application got a percentage of $84.4 \%$, the display aspect got a percentage of $91 \%$, the material delivery aspect got a percentage of $82 \%$, the beneficial aspects of using the emodule application got a percentage of $82 \%$. The average percentage result obtained from all aspects is $81.72 \%$ included in the "very good" category and declared "very feasible" as a learning medium to be used in the learning process. The use of this learning media can be used as a tool that aims to facilitate the delivery of messages so that the core material in learning can be conveyed completely to students [11].

\section{E. Evaluation}

The evaluation stage is a stage that aims to improve the development of learning media so that they are suitable and suitable for use in the learning process. Before being in the evaluation stage, the development of this learning media has gone through several stages of improvement, which are in the development and implementation stages. The results of the final assessment get a percentage of $81.72 \%$, meaning that the 
media developed is very suitable for use in the learning process. This android-based e-module has been improved based on the advice given by experts and respondents. The Android-based e-module learning media application can be uploaded and installed on an Android-based smartphone using a link https://drive.google.com/file/d/1HbdELxHs7Oz_GFgJmOKLU I swVSucq5JR/view?usp=sharing

\section{F. Answers to Quiz Questions and Exercises on Media}

From 50 students, only 23 students have participated in doing the practice questions contained in the application. Writing skills is the last sequence in the learning process after listening, speaking, and reading skills. Of the four sections, only writing skills are the most difficult to master.

From 50 students, respondents who participated in filling out the quiz were only 34 students. This is due to the existence of some students who do not have quotas to access the internet and some students who do not have smartphones with large free space capacity. In the quiz questions, there were 34 students filled in the questions, including 27 students who exceeded the KKM score, while there were 7 students who had not passed the KKM.

\section{CONCLUSION}

- The process of developing an Android-based e-module learning media uses the ADDIE method. Applications created using Microsoft Office Power Point applications and some software such as ispring, java set up, and the 2APK website.

- The results of the feasibility of learning media for emodule based on android according to the assessment of media experts are very feasible, material experts are feasible, and according to linguists are feasible to be used as learning media with several revisions The response of students stated that it was very suitable to be used as a learning medium.
- The learning outcomes of students can be seen in the scores obtained. As many as 34 students worked on quiz questions with a KKM score of 78, 27 students scored beyond the KKM, while 7 students did not exceed the KKM. For learning outcomes with practice questions, all students get a score of 100 .

\section{REFERENCES}

[1] M.S. Hidayatullah and L. Rakhmawat, "Development of Learning Media Based on the Flip Book Maker in Basic Electronics Subjects at SMK Negeri 1 Sampang," Journal of Electrical Engineering Education, vol. 5, no. 1, pp. 53-88, 2016.

[2] D.G.H. Divayana, P.W.A. Suyasa, and A. Adiarta, "Kvisoft Flipbook Maker Based Digital Book Making Training for Teachers at SMK Ti Udayana," National Journal of Informatics Engineering Education, vol. 1 , no. 2, 2018

[3] E. Wibowo, "Development of E-Module Teaching Materials Using the Kvisoft Flipbook Maker Application," In Thesis. Lampung: Faculty of Tarbiyah and Teacher Training, UIN Raden Intan, 2018.

[4] D. Daryanto, Learning Media Its Role Is Very Important In Achieving Learning Goals. Yogyakarta: Gava Media, 2013.

[5] S. Akbar, Learning Equipment Instruments. Bandung: PT. Rosdakarya youth, 2013.

[6] Marlina, Rustiyarso, and Parijo, The Influence of Limited Learning Resources on Learning Outcomes of Class VIII Students of SMP Negeri 1 Lumar. Research Articles. Pontianak: Tanjungpura University, 2014.

[7] V. Sanjaya, Planning and Design of Learning Systems. Jakarta: Golden, 2008.

[8] S. Siahaan, "E-Learning (Electronic Learning As An Alternative To Learning Activities," Journal of Education and Culture, No. 042, 2003.

[9] S. Arikunto, Research Methods: A Practical Approach. Volume 2. Jakarta: PT Rineka Cipta, 2006.

[10] Ministry of Education, Instructional Material Development Guide. Jakarta: Directorate of Primary and Secondary Education, Directorate of Education Personnel, 2008.

[11] Rusman, Computer-Based Learning and Learning: Developing 21st Century Teacher Professionalism. Bandung: Alfabeta, 2013. 